\title{
Armed Conflict and Girl Child
}

\author{
Rangili Brahma \\ Asst. Professor, Deptt. of Political Science, Kokrajhar Govt. College, Kokrajhar, Assam, India
}

\begin{abstract}
The $21^{\text {st }}$ century is not free from war and conflict. Conflict is one of the struggles which every country is facing. It affects the whole society and paralyzes the system of development .Girl child and women are one which faces tremendous amounts of challenges in the conflicting areas. Women are considered as most weak members of the human society. But half of the population of the world is constitute by women. Yet they are discriminated in all societies and violated of their rights and freedom. There are various rights given for her but still they are in the wake of discrimination. The people of North -East India are in no exception to armed conflict due to the rising number of ethnic assertion and identity problems. It has been remained as a disturbed area for decades. Bodo people of Assam are also the one who are fighting for their rights and identity. In this paper an attempt has been made to understand the plight of the condition of women and girl child in the armed conflict situation.
\end{abstract}

Keywords: Community, Conflict, Ethnic, Identity, Women.

\section{INTRODUCTION}

Conflicts are characterized by a total breakdown of law, security and community structures, with gross human rights violations perpetrated against civilian population. The most vulnerable are women and children. North East India is known from decades in India and to the world as the hotpot of ethnic violence, insurgency and extremism. The region is witnessing various kinds of violence which threaten the sovereignty and integrity of the nation. Assam is comprised of multi- ethnic groups and subgroups. Among the diverse groups some are demanding for autonomy for their rights and others try to secede from Indian Union in order to protect and preserve their identity. The people of this region feel neglected and thus there is a regular feature of unrest which affects the society. The Assam movement had given inspiration to the various groups to fight for their identity. The migration of people from Bangladesh is the main problem behind the movement. After the movement still there is problem in dealing with the immigration which has arisen due to influx from Bangladesh. Now today the question of National Registration Certificate (NRC) here arises due to such rise in number of population. Many children have lost their lives or become orphans in bomb blasts, attacks by militant groups such as the ULFA, the NDFB, the Dima Halam Daoga(j) and the Karbi Peoples Liberation Army in the past decades in Assam. Bodoland Territorial Council (BTC) is the conflict prone area of Assam. Bodo people belong to aboriginal ethnic tribe. They are launching ethnic movement and insurgency movement to have their identity. The conflict which occurred due to such identity movement of Bodos in Assam between 1993,1996, 1998,2008 and recently on 2012 have left a great impact on the society and the people. Thousands of people had to flee their homes. Many were killed and become victims of violence. Men, women and children are equally sufferers in the conflict but it is the women and children who face tremendous problems including the security of their life. According to the survey conducted by NEDAN foundation, in 1998 conflict 1220 girls in the age group of 5-20 years from 20 villages and towns have to stay in the relief camps. Women are weak sex of the society and during the time of conflict they are the easiest prey to violence. Girl children are victims of uncountable kinds of violence in the society and in the conflict areas they had to face and sacrifice their lot of things. These violations include illegal detention with or without family members, abduction and forced removal from families and homes, disappearances, torture and other inhuman treatment, amputation and mutilation, forced recruitment into fighting forces and groups, slavery, sexual exploitation, increased exposure to HIV/AIDS, and a wide range of physical and sexual violations, including rape, enforced pregnancy, forced prostitution, forced marriage and forced child bearing [1], etc. Conflict give loses to everything. So, there is an urgent need of the hour to protect the girl child who is very much affected by the armed conflict during and after. 


\section{OBJECTIVES OF THE STUDY}

The main objectives of the study are as follows:

1. To identify the sufferings or problems faced by the girl child during armed conflict.

2. To identify the remedies of the problems faced by girl child.

\section{METHODOLOGY}

The methodology that is used in this paper is historical. The information was collected from the available resources like books, journals, magazines, newspapers, websites, articles and other archival records both official and non-official.

\section{OVERVIEW}

Ethnic conflict has drastically damaged the four districts-Kokrajhar, Chirang, Baksa and Udalguri of Bodoland Territorial Council in Assam. Bodos are the main inhabitants of this place along with other communities. But due to the demand of Bodos for their land and rights there is a regular conflict. The conflict affects the society in large way- not only a group of people are affected here but it gives pain to the far off places people as well. It is seen that in the conflict people have to leave their homes and properties, they are displaced and had to flee to the relief camps. Some are killed, and many had to run for their lives. Children in such situation face devastating problems. They because of their age were ignorant of the happenings but have to learn the horrible situation of conflict. The conflict gives them loss of their parents, the loss of their homes, food security, education and many more. Girl child are supposed to be the main sufferers here with women.The word "child" has been defined differently by different policies and legislators in India. According to the United Nations Convention on the Rights of the Child (UNCRC), the juvenile Justice (Care and Protection of children) Act 2000 defines a "juvenile" or "child" as a person who has not completed 18 years of age. Under the Immoral Trafficking Prevention Act (ITPA), 1956, the age prescribed for a child is 16 years. The laws regulating employment, such as the Child Labour (Prohibition and protection) Act, 1986, the Factories Act, 1948, and the Mines Act1952, prohibit employment of children less than 14 years only, in line with the constitutional provision. There has been no uniformity in respect of the definition of "child" under different acts and other instruments [2]. Girls child are very much neglected in the conflict as well after the conflict they had to face several kinds of problems. The trauma of horrifying disaster, pain of losing, mental disturbance surrounds their live.

Graca Machel, in her 2001 report, called for urgent global action to increase children's protection in armed conflict: "The lives of children are jeopardized when women are not protected and when women's contributions to peace building are undermined and marginalized.... The glaring gaps in the protection of women and girls must be addressed through better focused humanitarian relief and development assistance" [3]. The UN Secretary general noted in his 2004 report on Security Council Resolution 1325(2000) on women, peace and security: "Resolution 1325(2000) holds out a promise to women across the globe that there rights will be protected and that barriers to their equal participation and full involvement in the maintenance and promotion of sustainable peace will be removed. We must uphold this promise"[4].

In 2009, UNICEF released a report concerning children in conflict areas. It discusses the changing faces of war conflict and war in the today world. There has been a decrease in inter-state conflict but conflict within countries and across borders is on the rise, where the state is using para-military and proxy forces to fight these hidden wars and armed forces have little accountability to the international community.

The draconian laws like Assam Disturbed Area Act, the Armed Forces Special Powers Act 1958, Prevention of Terrorist act as well as the Operation all out in order to erase the insurgency in many states of the country have given rise to crime in the states. It is creating a terror of insecurity in our homes. In the name of search or to nape the rebels of insurgency or armed conflict there are taking away the girls for rape, loot the house, beat the innocent villagers of no any cause, and take away the young youths to torture.

\section{SOME CASES OF VIOLATION OF RIGHTS OF GIRL CHILD :}

Three Bodo girls were killed by the Santhals in May 1996 which resulted in the violence between the Adivasis and Bodos.On November27, 2003 , a 21 year old mentally challenged girl was raped by army jawans at Matiapara village near Gossaigaon in Kokrajhar district.On $29^{\text {th }}$ March 2014, a girl was gang raped and killed by illegal Bangladeshi Muslim migrants in Chirang district.In May 2014, at least 26 children out of 45 people had been killed when the National Democratic Front of Bodoland (NDFB) militant group attacked NK Khagrabari village in Baksa and Balapara in Kokrajhar districts.Priya Basumatary, a class 9/10 student of 
Runikhata Girls' High School in Laimati- Dwimuguri village, was brutally gunned down on August 20, 2014, in the Bodoland Territorial Area Districts (BTAD) in front of her parents by the anti-talk faction of the National Democratic Front of Bodoland (NDFB), which suspected her to be a police informer. They dragged the girl out of her house and beat her up severely before killing her. Her parents were also beaten up severely.

The All Bodo Students' Union (ABSU) thus has appealed to the militant and security forces not to use women and children in their armed fight. They had also moved to the National Commission for protection of Child Rights (NCPCR).

\section{ARMED CONFLICT AND THE EFFECT ON GIRL CHILD:}

The plight of girl child in conflict is very worse and it is very difficult to explain how they are living in such condition.

1) Internally Displaced Persons:

The girl child at the time of conflict had to face the loss of their family members and had to accept the large vacuum of the parents and family members. According to a report by Asian -Pacific Human Rights Network, over 200,000 IDP'S now live in 78 relief camps in Kokrajhar district and Bongaigaon district of Assam.

2) Early Marriage:

During the conflict as because of teenage age some of the girl child are easily prey to trafficking, rape, forced recruitment to forces, slavery etc. due to these parents forced those to get marry at the early age. It is seen in many relief camps that girl child had to face the difficult situation of staying in such mass gathering.

3) Education:

Armed conflict adversely affect child in the sphere of education and development. It is seen that children had to drop their studies at the continuing stage or they cannot perform well in their studies due to mental disturbance of conflict. Many had to leave their studies of not having enough money, materials, due to loss of their documents, etc. Girl child had to leave education as to earn their living and work as servant in the others house. No doubt some of the NGO's have come up to help them but many left their studies.

4) Child Soldiers:

Child soldiers are seen as one of the most recent trends in the armed conflict. Children are recruited as soldiers by the militant groups. The situation of conflict and the helpless condition, as because of weaker sections children are target to become rebels. They are coerced, lured, influenced or had no other option of future development. Sometimes the parents want their children to earn due to poverty.

5) Abduction:

Children in conflict had to face the abduction. A girl child is abducted to make forced soldier or to get involve them in some sexual exploitation service. They are coerced to give service to the forces by cooking, cleaning the clothes, maintaining the camps, etc.

6). Violation of girl rights by Indian army or Para-military forces:

The government in order to control the situation of armed conflict has given an opportunity to the hungry army jawans to prove their cruelty over the innocent girl and women of conflict affected areas. The government impose para-military forces to stop the conflict but they themselves use the opportunity and in the absence of the members of the family in the name of search for a militant group they brutally rape, torture and harassed innocent girl or women.

7). Physical Health and hygiene:

Children in armed conflicts had to stay in relief camps. There they had no basic amenities as well as had to live in extremely poor condition. The scarcity of food and hygiene made the condition worst. The pregnant women, new born child had to stay in such unhygienic situation. Many had to die due to absence of proper medicine and health care. They suffer from various kinds of diseases like diarrhea, cholera, malaria, etc. There is an acute shortage of medicine or proper health care in the conflict prone areas.

8) Mental and Psychological impact:

The incident of conflict deeply affects the children mentally and psychologically. The feeling of pain of losing their near and dear ones, losing their homes, the disturbance create imbalance in the life of the children. They are having nightmares at night, become aggressive, demoralize, insecure, uncertainty of their future changed them mentally and psychologically.

9) Child trafficking:

The girl child is easy prey to traffickers. It is reported that Assam is ranked as one of the eight Indian states with regard to the Child Trafficking (UNODC, REPORT 2013). The Bodoland Territorial Area District have a regular feature of conflict and due to the backward area child trafficking is in an alarming scale in this 
region. Girls are also supplied to the forces for sexual exploitation. Sometimes they fall in the sex trade racket who promised them to give good service in the company to earn their bread.

\section{REMEDIES OR SUGGESTION}

(i) The health and hygiene should be given importance in the armed conflict areas. The trained doctors and staff should be employed to mitigate such shortage.

(ii) The government and NGOs should create alternative livelihood for vulnerable women and children.

(iii) Proper rehabilitation and relief compensation should be given to the people for rebuilding their losses.

(iv) Counseling should be given by the mental experts to remove mental disturbance of conflict.

(v) Strict rules should also to be followed in dealing with matters of violation of girl rights.

(vi) Educating the children after the loss of conflict should be taken by the government and NGOs'.

(vii) Recruitment of the child soldiers will break the eagerness of development. It must not be given chance to rise.

(viii) Abduction should be stopped in order to eradicate human trafficking, forced recruitment to soldiers, etc.

(ix) Early marriage will not solve the problem of violation of child rights. Parents should not encourage it but teach their children to fight against such problem.

(x) There should be more community leaders to work for the peace building and harmony to the people in conflict.

\section{CONCLUSION}

North-east India is one of the most conflict affected states of India. Insurgency, ethnic -conflict is now regular features of the life for the people of North-east India. The rise of conflict has deeply torn the hearts of millions of people to survive in peaceful environment here. It is believed that some of the measures are taken to fight the growing number of violence in the society yet people have to face crisis in dealing with their problems .Peace building measure should be build in a strong way in order to lessened the fear, aggressiveness, mental disturbances of the children due to conflict. Everyone should take an initiative to end the menace of violence from the society. It will take a long time to erase their miseries and sufferings but we should try to give better future for the children and work for it. Children of today are tomorrows' stake holders. So, let us have a better future for them. The people of conflict should be given humanitarian assistance as well as employment and livelihood facilities to restart their life. Government and NGO should work together in order to make an effort to these growing number of challenge which posed to the society. The international instrument should focus on the effective implementation of the countries of the world to end and improve the condition of conflict affected people.

\section{REFERENCE}

[1]. Dyan mazurana and Khristopher Carlson1, "The girl child and armed conflict: Recognizing and addressing grave violations of girls' human rights".pp2

[2]. Third and Fourth Combined Periodic Report on the Convention on the Rights of the Child, 2011,MWCD, Government of India, pp39.

[3]. The Impact of Conflicts on women and girls in West and Central Africa and the UNICEF Response,pp2

[4]. UN Secretary Report to the Security Council on Women, Peace and Security, 2004.

\section{Books:}

[5]. Biswal Tapan, "Human Rights Gender and Environment" Viva Books, New Delhi, 2006.

[6]. Phukon Dolly, "Insurgency Movement and Gender implications in Assam: Understanding the Role of ULFA and the Indian State". 